\title{
RISIKO, GOOD CORPORATE GOVERNANCE, PROFITABILITAS, CAPITAL TERHADAP KESEHATAN BANK UMUM SWASTA NASIONAL DEVISA DI INDONESIA
}

\author{
Shanty Rahayuningtyas ${ }^{1}$, Emanuel Kristijadi ${ }^{2}$ \\ 1,2) Sekolah Tinggi Ilmu Ekonomi Perbanas Surabaya
}

\begin{abstract}
The purpose of this study was determine whether CKPN, ALR, BOPO, IRR, GCG, ROA and ETA have a significant effect either simultaneously or in part. This study used the population of the National Private Foreign Exchange Bank in Indonesia, with a purposive sampling technique. The data used are secondary data taken from the Financial Services Authority website and the Infobank Research Bureau, with data collection methods using the documentation method and data analyzed using panel data and multiple linear regression. The results of this study indicate that CKPN, ALR, BOPO, IRR, GCG, ROA and ETA simultaneously have a significant effect on the Health Scores of National Foreign Exchange Private Banks in Indonesia. $C K P N, A L R, G C G$ partially have insignificant negative influence, BOPO and ETA partially have insignificant positive influence, IRR partially has significant negative influence and ROA partially has a significant positive effect on the Health Score of Private Foreign Exchange National Banks in Indonesia.
\end{abstract}

Keywords : Business Risk; Good Corporate Governance; Health Score

Correspondence to : shantyrahayuningtyass@gmail.com

\section{ABSTRAK}

Tujuan dari penelitian ini adalah untuk menentukan apakah CKPN, ALR, BOPO, IRR, GCG, ROA dan ETA memiliki pengaruh signifikan baik secara simultan atau sebagian terhadap Skor Kesehatan Bank Umum Swasta Nasional Devisa di Indonesia. Penelitian ini menggunakan populasi Bank Nasional Devisa Swasta di Indonesia, dengan teknik pengambilan sampel purposive sampling. Data yang digunakan adalah data sekunder yang diambil dari situs web Otoritas Jasa Keuangan dan Biro Riset Infobank, dengan metode pengumpulan data menggunakan metode dokumentasi dan data dianalisis menggunakan data panel serta regresi linier berganda. Hasil penelitian ini menunjukkan bahwa CKPN, ALR, BOPO, IRR, GCG, ROA dan ETA secara simultan memiliki pengaruh yang signifikan terhadap Skor Kesehatan Bank Umum Swasta Nasional Devisa di Indonesia. CKPN, BOPO, ALR, GCG dan ETA secara parsial memiliki pengaruh tidak signifikan, IRR secara parsial memiliki pengaruh negatif signifikan dan ROA secara parsial memiliki pengaruh positif signifikan terhadap Skor Kesehatan Bank Nasional Devisa Swasta di Indonesia.

Kata kunci

Korespondensi
: Risiko Usaha; Good Corporate Governance; Skor Kesehatan

:shantyrahayuningtyass@gmail.com 


\section{PENDAHULUAN}

Menurut Undang-Undang Perbankan

No.7 tahun 1992 tentang perbankan yang telah diubah menjadi Undang-Undang No. 10 tahun 1998 yang menjelaskan pengertian bank sebagai perusahaan yang bergerak di bidang jasa dan memiliki kegiatan pokok dengan fungsi pokok, fungsi umum dam fungsi khusus. Berdasarkan fungsi pokok, fungsi umum dan fungsi khusus bank tersebut bank wajib menjaga kepercayaan nasabahnya, kepercayaan nasabah merupakan hal yang sangat penting agar kegiatan operasional dapat berjalan dengan baik. Untuk menjaga kepercayaan nasabah, bank-bank yang beroperasi perlu di nilai tingkat kesehatannya. Tingkat kesehatan bank dapat dinilai dari beberapa indikator, salah satu sumber yang dapat dijadikan bahan penilaian adalah melalui laporan keuangan yang diterbitkan oleh bank yang bersangkutan. Menurut Peraturan Otoritas Jasa Keuangan Nomor 4/POJK/.03/2016 dasar-dasar dalam menentukan atas penilaian kesehatan suatu bank terdiri atas beberapa unsur yakni Profil Risiko (Risk Profile), Good Corporate Governnace (GCG), Rentabilitas (Earning) dan Permodalan (Capital). Berbagai unsurunsur tersebut merupakan satu kesatuan yang tidak dapat dipisahkan dan juga saling melengkapi dalam metode Risk Based Banking Ratio (RBBR) dimana yang dimaksud dengan Risk Based Banking Ratio (RBBR) yakni metode terbaru yang digunakan untuk melakukan suatu penilaian kesehatan suatu bank, adapun metode sebelumnya pernah ada yakni metode Camels.

Penilaian skor kesehatan bank juga dilakukan oleh Biro Riset InfoBank yakni lembaga independen yang menetapkan kritera-kriteria dan pembobotan yang tediri atas tujuh kriteria antara lain Peringkat Profil Manajemen Risiko, Peringkat Nilai Komposit GCG, Rentabilitas, Likuiditas, Efisiensi, Permodalan dan Kualitas Aset. Dimana kriteria-kriteria tersebut dinyatakan dalam nilai total dalam bentuk skor kesehatan bank. Hasil skor kesehatan bank yang dibuat oleh Biro Riset InfoBank dinyatakan dalam bentuk persentase mulai dari nol sampai dengan seratus persen, hasil tersebut dipublikasikan dalam majalah InfoBank secara berkala. Hal ini yang menjadi dasar perlunya dilakukan penelitian untuk membuktikan bahwa apakah faktor CKPN, ALR, BOPO, IRR, GCG ROA dan ETA berngaruh terhadap kesehatan Bank Umum Swasta Nasional Devisa di Indonesia. Penelitian ini bertujuan untuk mengetahui tingkat signifikansi pengaruh CKPN, ALR, BOPO, IRR, GCG ROA dan ETA secara bersama-sama terhadap skor kesehatan Bank Umum Swasta Nasional Devisa di Indonesia.

Penelitian terdahulu yang dilakukan oleh Md. Zahidur Rahman, Md. Shohidul Islam (2018) penelitian ini dilakukan untuk mengevaluasi dan membandingkan kinerja keuangan pada 17 bank umum swasta yang beroperasi di Bangladesh. Data yang digunakan merupakan data sekunder yang dikumpulkan dari laporan tahunan bank umum swasta pada periode 2010 sampai dengan 2016. Penelitian ini menggunakan 24 sub-parameter dalam model CAMEL yang telah dipertimbangkan serta dikaitkan dengan berbagai dimensi analisis kinerja keuangan. Hasil dari penelitian ini yakni rata-rata rasio Kecukupan Modal dari semua bank jauh lebih tinggi daripada patokan $10 \%$ seperti yang diamanatkan oleh Bangladesh Bank. Ratarata CAR Bank Kota adalah yang tertinggi $(12,90 \%)$ di antara semua bank. Karena NPL Bank Kota $(6,94 \%)$ jauh lebih tinggi daripada bank lain .

Penelitian terdahulu yang dilakukan oleh Azehari, dkk (2017) penelitian ini dilakukan untuk menganalisis kinerja keuangan tiga bank pemerintah di Indonesia (BNI, BRI, dan Bank Mandiri) untuk periode 2011-2015 dengan menggunakan pendekatan RGEC. Hasil dari penelitian ini yakni Risiko 
kredit yang diwakili oleh rasio NPL dinilai sehat, Risiko likuiditas yang diwakili oleh rasio LDR juga dinilai sehat. Dari aspek Good Corporate Governance (GCG), kinerja bank dinilai sangat sehat. Kinerja Keuangan keseluruhan dari aspek Earning yang dihitung dengan menganalisis rasio NIM dan ROA juga dinilai sehat. Terakhir, kinerja keuangan keseluruhan dari aspek Capital yang dihitung dengan menganalisis perbandingan antara rasio modal terhadap Aktiva Tertimbang Menurut Risiko (ATMR) yang diwakili oleh rasio CAR yang dinilai sehat.

Adanya perbedaan kesimpulan pada beberapa penilitian terdahulu tersebut menjadikan perlunya dilakukan penelitian ulang terhadap skor kesehatan bank umum. (Peraturan Otoritas Jasa Keuangan Nomor 4/POJK.03/2016).

Kesehatan Bank

Menurut Peraturan Otoritas Jasa Keuangan Nomor 4/POJK.03/2016 tentang penilaian tingkat kesehatan bank dalam melaksanakan tanggung jawab atas kelangsungan usaha bank, direksi dan dewan komisaris bertanggung jawab untuk memlihara serta memantau tingkat kesehatan bank dan juga mengambil langkah-langkah yang diperlukan untuk memilhara serta meningkatkan tingkat kesehtaan bank. Dengan demikian suatu bank wajib melaksanaakan penilaian tingkat kesehatan dengan menggunakan metode Risk Based Banking Ratio (RBBR), dalam hal ini secara individu ataupun secara konsolidasi dengan melakukan penilaian sendiri. Yang dimaksud dengan metode Risk Based Banking Ratio (RBBR) yakni suatu metode yang dapat digunakan untuk mengukur tingkat kesehatan suatu bank melalui berbagai pendekatan risiko, dalam metode ini terdapat faktorfaktor yang dapat digunakan dalam penilaian antara lain Profil Risiko, Penilaian GCG, Rentabilitas serta Permodalan. Faktor penilaian tingkat kesehatan bank telah dtetapkan peringkatnya berdasarkan kerangka analisis yang komprehensif dan terstruktur. Peringkat komposit tersebut diantaranya :

Peringkat komposit 1 (PK-1) dimana menggambarkan suatu kondisi bank sangat sehat, Peringkat komposit 2 (PK-2) dimana menggambarkan suatu kondisi bank sehat, Peringkat 3 (PK-3) dimana menggambarkan suatu kondisi bank cukup sehat, Peringkat 4 (PK-4) dimana menggambarkan suatu kondisi bank kurang sehat secara umum sehingga sangat mampu menghadapi pengaruh negatif yang signifikan dari suatu perubahan kondisi bisnis serta faktor-faktor eksternal. (Peraturan Otoritas Jasa Keuangan Nomor 4/POJK.03/2016). Adapun kriteria penting tersebut diantaranya peringkat Profil Manajemen Risiko, Peringkat Nilai Komposit GCG, Permodalan, Kualitas Aset, Rentabilitas, Likuiditas, Efisiensi. Menurut versi majalah biro riset infobank tahun 2019, bobot nilai yang diberlakukan yaitu sebagai berikut yang terdapat pada tabel 1 .

TABEL 1. Predikat Bank

\begin{tabular}{cc}
\hline Nilai Antara & Predikat \\
\hline 0 s.d. $<51$ & Tidak Bagus \\
\hline 51 s.d.. $<66$ & Cukup Bagus \\
\hline 66 s.d. $<81$ & Bagus \\
\hline 81 s.d.100 & Sangat Bagus \\
\hline \multicolumn{2}{l}{ Sumber: Biro Riset Infobank 2019, data diolah. }
\end{tabular}

Risiko Usaha Bank

Menurut Peraturan Otoritas Jasa Keuangan Nomor 18/POJK.03/2016, risiko adalah suatu potensi kerugian yang diakibatkan oleh terjadinya suatu peristiwa tertentu. Terdapat delapan jenis risiko yang harus dikelola oleh bank, yaitu risiko kredit, risiko pasar, risiko likuiditas, risiko operasional, risiko kepatuhan, risko hukum, risiko reputasi dan risiko strategis. Adapun risiko yang hanya dapat diukur dengan menggunakan rasio keuangan, antara lain risiko likuiditas, risiko kredit, risiko pasar dan risiko operasional. 
1. Risiko Kredit

Menurut Peraturan Otoritas Jasa

Keuangan Nomor 18/POJK.03/2016 risiko kredit adalah risiko akibat kegagalan pihak lain dalam memenuhi kewajiban kepada Bank, termasuk risiko kredit akibat kegagalan debitur, risiko konsentrasi kredit, counterparty credit risk, dan settlement risk Dalam menilai risiko inheren atas risiko kredit, parameter yang digunakan yakni komposisi portofolio aset dan tingkat konsentrasi, kualitas penyediaan dana dan kecukupan pencadangan, strategi penyediaan dana dan sumber timbulnya penyediaan dana, dan factor Eksternal (Taswan; 2010:164-167). Rasio yang digunakan yakni :

a. Cadangan Kerugian Penurunan Nilai

Rasio yang digunakan untuk menunjukkan besarnya presentase rasio cadangan perselisihan atau cadangan yang dibentuk terhadap total kredit yang diberikan (Taswan ; 2010:164)

Rumus :

CKPN $=\frac{\text { CKPN Atas Kredit }}{\text { Total Kredit }} \times 100 \%$

Keterangan :

CKPN Kredit adalah nilai cadangan kerugian penurunan nilai untuk kredit yang tergolong diragukan, kurang lancar dan macet yang perhitungannya menggunakan pedoman standart akuntansi.

Total kredit adalah kredit yang diberikan kepada pihak ketiga bukan bank .

2. Risiko Likuiditas

Menurut Peraturan Otoritas Jasa Keuangan Nomor 18/POJK.03/2016, risiko likuiditas adalah risiko akibat ketidakmampuan bank untuk memenuhi kewajiban yang jatuh tempo dari sumber pendanaan arus kas dan atau dari aset likuid berkualitas tinggi yang dapat diagunkan, tanpa menggangu aktivitas dan kondisi keuangan bank. Rasio yang digunakan yakni: a. Aset Liquid Rasio

Menurut Surat Edaran Bank Otoritas

Jasa Keuangan Nomor 14/SEOJK.03/2017

Tanggal 17 Maret 2017

Rumus :

$$
\text { ALR }=\frac{\text { ALP }+ \text { ALS }}{\text { Total Aset }} \times 100 \%
$$

Keterangan :

Aset likuid primer adalah asset yang sangat likuid untuk memnuhi kebutuhan likuiditas atas penarikan dana pihak ketiga dan kewajiban jatuh tempo, yang terdiri atas Kas, Penempatan pada Bank Indonesia berupa Fine Tune Operation (FTO), Fasbi, dan lainnya, Surat berharga kategori tersedia untuk dijual (Available for Sales/AFS) atau trading, Seluruh surat berharga pemerintah (government bonds) kategori trading dan AFS yang memiliki kualitas tinggi, diperdagangkan pada pasar aktif, dan memiliki sisa jatuh waktu 1 tahun atau kurang.

Aset likuid sekunder adalah sejumlah asset likuid dengan kualitas lebih rendah untuk memnuhi kebutuhan likuiditas atas penarikan dana pihak ketiga dan kewajiban jatuh tempo, yang terdiri atas Surat berharga pemerintah (government bonds) kategori trading dan AFS dengan kualitas baik, diperdagangkan pada pasar aktif, dam memiliki sisa jatuh waktu lebih dari 1 tahun tapi kurang dari 5 tahun, Surat berharga pemerintah (government bonds) kategori HTM dan memiliki sisa jatuh waktu sampai dengan 1 tahun, Surat berharga pemerintah (government bonds) kategori trading dan AFS dan memiliki sisa jatuh waktu lebih dari 5 tahun, dengan nilai haircut 25 persen.

Total aset adalah total asset secara neto (setelah set-off atar kantor) sesuai yang tertera pada Laporan Bulanan Bank Umum.

3. Risiko Operasional

Menurut Peraturan Otoritas Jasa Keuangan Nomor 18/POJK.03/2016, risiko operasional adalah risiko akibat ketidakcukupan dan atau tidak berfungsinya 
proses internal, kesalahan manusia, kegagalan sistem, dan atau adanya kejadian kejadian eksternal yang mempengaruhi operasional bank. Rasio yang digunakan yakni :

a. Beban Operasional pada Pendapatan Operasioal

Rasio yang digunakan untuk mengukur seberapa efisien bank dalam mengelola dananya. Biaya operasional adalah seluruh biaya yang dikeluarkan yang berkaitan dengan kegiatan operasional bank yaitu terkait operasional bank dalam kegiatannya menjaankan fungsinya. (Veithzal,dkk 2013:482) :

Rumus :

$$
\text { BOPO }=\frac{\text { Biaya Operasional }}{\text { Pendapatan Operasional }} \times 100 \%
$$

Keterangan :

Biaya operasional adalah seluruh biaya yang dikeluarkan dan berkaitan dengan kegiatan operasional bank yang terdiri atas biaya bunga, biaya provisi komisi, biaya transaksi devisa, biaya tenaga kerja, biaya penyusutan dan biaya rupa-rupa

$$
\text { Pendapatan operasional adalah }
$$
pendapatan operasional bank yang terdiri atas hasil bunga, pendapatan provisi komisi, pendapatan transaksi devisa dan pendapatan rupa-rupa

\section{Risiko Pasar}

Menurut Peraturan Otoritas Jasa Keuangan Nomor 18/POJK.03/2016 , risiko pasar adalah adalah risiko pada posisi neraca dan rekening administratif, termasuk transaksi derivatif, akibat perubahan secara keseluruhan dari kondisi pasar, termasuk risiko perubahan harga option. Risiko pasar meliputi risko tingkat suku bunga (IRR) dan nilai tukar (PDN). Rasio yang digunakan yakni:

a. Interest Risk Ratio

Faktor risiko yang mengacu pada sensitivitas pasar keseluruhan portofolio bank baik jangka panjang dan jangka pendek (Frianto Pandia 2012:209).
Rumus :

IRR $=\frac{\text { IRSA }}{\text { IRSL }} \times 100 \%$

Keterangan :

IRSA yaitu asset keuangan dengan jatuh tempo diatas satu tahun yang meliputi penempatan pada bank lain, tagihan akseptasi, surat berharga reserve repo dan kredit dengan jatuh tempo diatas satu tahun dengan bunga tetap.

IRSL yaitu simpanan berjangka, kewajiban repo, kewajiban akseptasi, kewajiban pada bank lain, surat berharga yang diterbitkan dan pinjaman yang diterima dengan suku bunga tetap.

\section{Good Corporate Governance}

Sehubungan dengan kewajiban bank untuk melakukan penilaian sendiri (self assessment) tingkat kesehatan bank dengan menggunakan pendekatan risiko (Risk Based Bank Rating/RBBR) baik secara individu maupun secara konsolidasi yang antara lain mencakup penilain faktor Good Corporate Governance (GCG), terdapat prinsip-prinsip dasar penerapan GCG menurut Peraturan Otoritas Jasa Keuangan Nomor 55/POJK.03./2016 Tentang Penerapan Tata Kelola Bagi Bank Umum yaitu Transparansi (transparency) yaitu keterbukaan dalam mengemukakan informasi yang material dan relevan serta keterbukaan dalam melaksanakan proses pengambilan keputusan, Akuntabilitas (Accountability) yaitu kejelasan fungsi dan pelaksanaan pertanggungjawaban organ Bank sehingga pengelolaannya berjalan secara efektif, Pertanggungjawaban (Responsibility) yaitu kesesuaian pengelolaan Bank dengan peraturan perundang-undangan yang berlaku dan prinsip pengelolaan Bank yang sehat, Independensi (Independency) yaitu pengelolaan Bank secara profesional tanpa pengaruh/tekanan dari pihak manapun; dan Kewajaran (Fairness) yaitu keadilan dan kesetaraan dalam memenuhi hak-hak stakeholders yang timbul berdasarkan 

Vol. XVII No. 2 |Bulan Juli Tahun 2020

perjanjian dan peraturan perundang-undangan yang berlaku.

Dalam rangka memastikan penerapan 5 (lima) prinsip dasar GCG, Bank harus melakukan penilaian sendiri (self assessment) secara berkala yang paling kurang meliputi 11 (sebelas) Faktor Penilaian Pelaksanaan GCG yaitu:

1. Pelaksanaan tugas dan tanggung jawab dewan komisaris

2. Pelaksanaan tugas dan tanggung jawab dewan direksi

3. Kelengkapan dan pelaksaan tugas komite

4. Penanganan benturan kepentingan

5. Penerapan fungsi kepatuhan

6. Penerapan fungsi audit intern

7. Penerapan fungsi audit ekstern

8. Penerapana manajemen risiko termasuk sistem pengendalian intern

9. Penyediaan dana kepada pihak terkait (relate party) dan penyedia dana besar (large exposure)

10. Transparansi kondisi keuangan dan non keuangan bank, laporan pelaksanaan GCG dan pelaporan internal

11. Rencana strategi bank

Fokus indikator struktur GCG yang diteliti pada penelitian ini yaitu komposisi komisaris independen. Dalam pelaksanaan GCG, diperlukan keberadaan Komisaris Independen dan Pihak Independen untuk menghindari benturan kepentingan (conflict of interest) dalam pelaksanaan tugas seluruh tingkatan atau jenjang organisasi Bank, check and balance, serta melindungi kepentingan stakeholders khususnya pemilik dana dan pemegang saham minoritas. Untuk mendukung independensi dalam pelaksanaan tugas dimaksud, perlu pengaturan mengenai masa tunggu (cooling off) bagi pihak yang akan menjadi pihak independen. Komposisi dewan komisaris independen memegang peranan penting dalam implementasi good corporate governance. Komisaris Independen adalah anggota Dewan Komisaris yang tidak memiliki hubungan keuangan, kepengurusan, kepemilikan saham dan/atau hubungan keluarga dengan anggota Direksi, anggota Dewan Komisaris lain dan/atau pemegang saham pengendali, atau hubungan dengan Bank yang dapat mempengaruhi kemampuan yang bersangkutan untuk bertindak independen. Komisaris Independen ditetapkan paling kurang 50\% (lima puluh persen) dari jumlah anggota Dewan Komisaris.

Rentabilitas

Rasio rentabilitas (earnings) atau yang sering disebut sebagai profitabilitas usaha. Rasio ini digunakan untuk mengukur tingkat efisiensi usaha dan profitabilitas yang dicapai oleh bank yang bersangkutan. Analisis rasio rentabilitas yakni penilaian terhadap kondisi dan kemampuan rentabilitas bank untuk mendukung kegiatan operasional dan permodalannya. Bank dikatakan sehat atau tidak dapat dilihat dari earning yakni kinerja keuangan dalam menghasilkan laba. Dalam hal ini Bank Indonesia sebagai pemegang otoritas tertingi untuk menilai. Penilaian dalam rentabilitas meliputi evaluasi terhadap kinerja rentabilitas, sumber-sumber rentabilitas, kesinambungan rentabilitas dan menejemen rentabilitas. Penilaian dilakukan dengan mempertimbangkan tingkat trend, struktur, stabilitas rentabilitas bank dan perbandingan kinerja bank dengan kinerja peer group baik melalui analisis aspek kuantitatif maupun kualitatif. Adapun indikator yang dapat digunakan untuk mengukur rentabilitas yakni) :

a. Return On Asset

Rasio yang digunakan untuk mengukur kemampuan manajemen bank dalam memperoleh keuntungan (laba) secara keseluruhan. Return On Asset (ROA) adalah salah satu rasio profitabilitas. Dalam analisis laporan keuangan rasio ini paling disoroti karena mampu menunjukkan keberhasilan perusahaan dalam menghasilkan keuntungan.

ROA mampu mengukur kemampuan e-ISSN : 2614-820X 
perusajaan dalam menghasilka keuntungan

(laba) pada masa lampau untuk kemudian diproyeksikan di masa yang akan datang. Return On Asset (ROA) merupakan salah satu rasio profitabilitas yang penting digunakan untuk mengetahui sejauh mana kemampuan aktiva yang dimiliki perusahaan dapat menghasilkan laba. Return On Asset (ROA) merupakan rasio laba bersih terhadap total aktiva. Semakin besar Return On Asset (ROA) maka dapat menunjukkan kinerja perusahaan semakin baik . Rasio yang digunakan yakni :

ROA $=\frac{\text { Laba Sebelum Pajak }}{\text { Total Aset }} \times 100 \%$

Keterangan :

- Laba sebelum pajak yakni keseluruhan laba yang diperoleh bank tersebut sebelum dikurangi pajak.

- Total aset meliputi keseluruhan asset yang dimiliki bank tersebut, baik asset tetap maupun asset lancar.

\section{Capital (Permodalan)}

Rasio permodalan (capital), untuk memastikan kecukupan modal dan cadangan untuk memikul risiko yang mungkin timbul. Modal merupakan benteng pertahanan bagi bank. Modal adalah faktor penting bagi bank dalam rangka pengembangan usaha dan penampungan kerugian. Agar mampu berkembang dan bersiang secara sehat maka permodalannya perlu disesuaikan dengan ukuran internasional yang dikenal sebagai standar BIS (Bank for International Settlement). Sesuai dengan BIS maka kewajiban modal minimum bank dalah berdasarkan pada risiko, termasuk dalam risiko kredit. Dengan demikian, permodalan merupakan penilaian terhadapan kecukupan modal bank untuk mengcover eksposur saat ini dan mengantisipasi eksposur risiko dimasa datang. Penilaian pendekatan kuantitatif dan kualitatif faktor permodalan antara lain dilakukan melalui penilaian terhadap komponen berikut ini :
1. Kecukupan pemenuhan Kewajiban Penyediaan Modal Minimum (KPMM) terhadap ketentuan yang berlaku;

2. Komposisi permodalan; Tren kedepan / proyeksi KPMM;

3. Aktiva produktif yang diklasifikasikan dibandingkan dengan modal bank;

4. Kemampuan bank memelihara kebutuhan penambahan modal yang berasal dari keuntungan (laba ditahan);

5. Rencana permodalan bank untuk mendukung pertumbuhan usaha;

6. Akses kepada sumber permodalan; dan

7. Kinerja keuangan pemegang saham untuk meningkatkan permodalan bank.

Sesuai dengan peraturan Bank Indonesia, pendekatan sebagai dasar dalam penilaian permodalan ini adalah sebagai berikut :

Kewajiban Penyediaan Modal Minimum (KPMM) Bank diwajibkan meyediaakan modal sebesar 8 persen dari Aktiva Tertimbang Menurut Risiko (ATMR) dengan catatan penilaian Bank Indonesia tidak terdapat faktor lain yang dapat menambah risiko diluar yang telah dihitung secara kuantitatif.

Semua bank diwajibkan memenuhi tingkat kecukupan pemenuhan modal (Capital Adequency Ratio-CAR) yang memadai untuk menjaga likuiditasnya. Bank juga tidak dapat semaunya menyalurkan kredit, apalagi terhadap institusi atau individu yang memiliki afiliasi dengan bank yang bersangkutan. Rasio yang digunakan yakni :

\section{Equity to Total Asset}

Rasio yang digunakan untuk mengukur apakah permodalan yang dimiliki sudah memadai atau sejau mana penurunan yang terjadi dalam total aset masuk dapat ditutupi oleh capital equity.

Rumus :

$$
\text { ETA }=\frac{\text { Equity Capital }}{\text { Total Aset }} \times 100 \%
$$

Keterangan : 
1. Equity capital terdiri atas modal disetor, dana setoran modal, cadangan umum, cadangan lainnya, sisa laba tahun lalu, laba tahun berjalan.

2. Total aset meliputi keseluruhan asset yang dimiliki bank tersebut, baik asset tetap maupun asset lancar.

\section{Gambar 1. Kerangka Pemikiran}

Hipotesis

Variabel CKPN, ALR, BOPO, IRR, GCG, ROA dan ETA secara bersama-sama mempunyai pengaruh signifikan terhadap Skor Kesehatan Bank Umum Swasta Nasinal Devisa di Indonesia. Variabel GCG, ROA dan ETA secara parsial memiliki pengaruh positif signifikan terhadap Skor Kesehatan Bank Umum Swasta Nasinal Devisa di Indonesia. Variabel CKPN dan BOPO secara parsial memiliki pengaruh negatif signifikan terhadap Skor Kesehatan Bank Umum Swasta Nasinal Devisa di Indonesia. Variabel ALR dan IRR secara parsial memiliki pengaruh positif atau negatif signifikan terhadap Skor Kesehatan Bank Umum Swasta Nasinal Devisa di Indonesia.

\section{METODE PENELITIAN}

Populasi dari penelitian ini adalah Bank Umum Swasta Nasional Devisa akan tetapi tidak semua bank diteliti. Sampel merupakan bagian dari populasi yang diharapkan dapat mewakili populasi penelitian. Teknik yang digunakan dalam pengambilan sampel yakni purposive sampling, dimana purposive sampling adalah cara pengambilan sampel yang didasarkan pada pertimbangan-pertimbangan atau kriteria-kriteria tertentu yang ditetapkan. Kriteria yang digunakan dalam penelitian ini yakni Bank Umum Swasta Nasional Devisa periode 2014 sampai dengan 2018 bukan termasuk bank syariah.
Data yang digunakan dalam penelitian ini merupakan data sekunder yang bersifat kuantitatif yang diambil dari majalah infobank yaitu mengenai rating 120 bank di Indonesia periode 2014 sampai dengan tahun 2018. Metode yang digunakan dalam penelitian ini merupakan metode dokumentasi dimana data yang diperoleh dari majalah infobank dan laporan keuangan yang dipublikasi oleh Otoritas Jasa Keuangan yang kemudian diolah dan dilakukan analisis data.

Teknik analisi statistik yang digunakan adalah analisi regresi data panel dengan bantuan program aplikasi komputer Stata. Dalam mengestimasi parameter pada Model Regresi Data Panel, terdapat tiga teknik tergantung pada asumsi yang digunakan. Adapun ketiga teknik tersebut, yakni Common Effect (Ordinary Least Square/OLS), Fixed Effect (FE) dan Random Effect (RE). Pemilihan teknik terbaik diantara ketiganya dilakukan dengan metode sebagai berikut:

\section{Chow Test}

Metode ini dilakukan untuk menentukan pilihan model terbaik antara OLS dan FE.

\section{Hausman Test}

Metode ini dilakukan untuk menentukan pilihan model terbaik antara FE dan RE. Uji ini dilakukan apabila pada Chow Test menyimpulkan bahwa model terbaik adalah FE, sehingga perlu ditentukan lagi pilihan terbaik antara FE dan RE.

Persamaan regresi yang diharapkan terbentuk dari penelitian ini adalah sebagai berikut :

$Y_{\text {it }}=\alpha+\beta_{1} X_{1}$ it $+\beta_{2} X_{2}$ it $+\beta_{3} X_{3}$ it $+\beta_{4} X_{4}$ it + $\beta_{5} X_{5}$ it $+\beta_{6} X_{6}$ it $+\beta_{7} X_{7}$ it $+e_{i t}$

Keterangan :

$\mathrm{Y} \quad=$ Skor Kesehatan Bank

$\alpha \quad=$ Konstanta

e it = Variabel Pengganggu

$\beta 1-\beta 7=$ Koefisien Regresi

$\mathrm{X} 1=\mathrm{CKPN}$

$\mathrm{X} 2=\mathrm{ALR}$

$\mathrm{X} 3=\mathrm{BOPO}$

$\mathrm{X} 4=\mathrm{IRR}$ 


$\begin{array}{ll}\mathrm{X} 5 & =\text { Komposisi Komisaris Independen } \\ \mathrm{X} 6 & =\mathrm{ROA} \\ \mathrm{X} 7 & =\mathrm{ETA} \\ \mathrm{I} & =1,2,3,4 \\ \mathrm{t} & =1,2,3 \ldots ., 22\end{array}$

Pembuktian Hipotesis pada penelitian ini dilakukan dengan Uji $\mathrm{F}$ dan Uji t yang dapat menunjukkan tingkat signifikansi pengaruh variabel bebas (CKPN, ALR, BOPO, IRR, Komposisi Komisaris Independen, ROA, IRR, ROA, ETA) terhadap variabel terikat (Kesehatan Bank).

\section{HASIL PENELITIAN}

Hasil analisis statistik yang diperoleh dalam penelitian ini adalah seperti yang ditunjukkan pada tabel 2.

TABEL 2. Hasil Pengolahan Data

\begin{tabular}{cccc}
\hline Variabel & $\begin{array}{c}\text { Koefisien } \\
\text { Regresi }\end{array}$ & $\mathbf{P}>|\mathbf{t}|$ & $\mathbf{r}^{\mathbf{2}}$ \\
\hline CKPN & $-34,967$ & 0,532 & $0,59 \%$ \\
\hline ALR & $-10,267$ & 0,511 & $0,00 \%$ \\
\hline BOPO & 10,216 & 0,305 & $0,03 \%$ \\
\hline IRR & $-12,189$ & 0,042 & $1,75 \%$ \\
\hline GCG & 2,829 & 0,536 & $3,68 \%$ \\
\hline ROA & 459,359 & 0 & $17,40 \%$ \\
\hline ETA & 2,635 & 0,664 & $0,39 \%$ \\
\hline
\end{tabular}

Sumber : Data pengolahan hasil Stata

Pengaruh CKPN Terhadap Skor Kesehatan

Berdasarkan koefisien regresi, $t$ hitung dan koefisien determinasi $\left(\mathrm{r}^{2}\right)$ pada tabel 2, diketahui bahwa CKPN memiliki pengaruh negatif yang tidak signifikan. Dengan demikian, hipotesis yang menyatakan bahwa CKPN secara parsial mempunyai pengaruh negatif yang signifikan terhadap Skor Kesehatan Bank pada Bank Umum Swasta Nasional Devisa ditolak.

Hasil penelitian dengan teori disebabkan karena secara teoritis apabila CKPN meningkat berarti telah terjadi peningkatan cadangan kerugian penurunan nilai atas kredit dengan persentase peningkatan yang lebih besar dibandingkan dengan persentase peningkatan total kredit yang diberikan. Hal ini menunjukkan bahwa potensi terjadinya kredit bermasalah akan meningkat, dengan demikian risiko kredit juga akan meningkat. Akibatnya akan terjadi peningkatan biaya pencadangan semakin besar dibanding peningkatan pendapatan bunga, sehingga pendapatan bank menurun dan laba bank juga akan menurun dan akan berpengaruh pada skor kesehatan bank sampel menurun. Selama periode penelitian skor kesehatan bank sampel penilitian mengalami penurunan yang dibuktikan dengan tren sebesar $-0,05$ persen.

Pengaruh ALR Terhadap Skor Kesehatan

Berdasarkan koefisien regresi, $t$ hitung dan koefisien determinasi $\left(\mathrm{r}^{2}\right)$ pada tabel 2, diketahui bahwa ALR memiliki pengaruh negatif yang tidak signifikan. ALR memberikan kontribusi sebesar 0 persen terhadap skor kesehatan bank. Dengan demikian, hipotesis yang menyatakan bahwa ALR secara parsial mempunyai pengaruh positif atau negatif yang signifikan terhadap Skor Kesehatan Bank pada Bank Umum Swasta Nasional Devisa ditolak.

Kesesuaian hasil penelitian dengan teori dikarenakan apabila ALR meningkat, berarti telah terjadi peningkatan aset likuid dengan persentase lebih besar dibanding persentase peningkatan aset karena peningkatan aset lebih banyak dialokasikan pada aset likudi, akibatnya pendapatan bank menurun, laba bank menurun dan skor kesehatan bank menurun. Selama periode penelitian skor kesehatan bank sampel penilitian mengalami penurunan yang dibuktikan dengan tren sebesar $-0,05$ persen.

Pengaruh BOPO Terhadap Skor Kesehatan

Berdasarkan koefisien regresi, $\mathrm{t}$ hitung dan koefisien determinasi $\left(\mathrm{r}^{2}\right)$ pada tabel 2, diketahui bahwa BOPO memiliki pengaruh positif yang tidak signifikan. BOPO memberikan kontribusi sebesar 0,03 persen 
terhadap skor kesehatan bank. Dengan demikian, hipotesis yang menyatakan bahwa BOPO secara parsial mempunyai pengaruh negatif yang signifikan terhadap Skor Kesehatan Bank pada Bank Umum Swasta Nasional Devisa ditolak.

Ketidaksesuaian hasil penelitian dengan teori dikarenakan apabila BOPO menurun, berarti telah terjadi peningkatan biaya operasional dengan persentase lebih kecil dibanding persentase peningkatan pendapatan operasional. Akibatnya pendapatan bank meningkat, laba bank meningkat dan skor kesehatan bank meningkat. Selama periode penelitian skor kesehatan bank sampel penilitian mengalami penurunan yang dibuktikan dengan tren sebesar - 0,05 persen. Hal ini karena kenaikan skor akibat BOPO lebih rendah daripada turunnya skor akibat faktor yang lain.

Pengaruh IRR Terhadap Skor Kesehatan

Berdasarkan koefisien regresi, $t$ hitung dan koefisien determinasi $\left(\mathrm{r}^{2}\right)$ pada tabel 2, diketahui bahwa IRR memiliki pengaruh negatif yang tidak signifikan. Dengan demikian, hipotesis yang menyatakan bahwa ALR secara parsial mempunyai pengaruh yang signifikan terhadap Skor Kesehatan Bank pada Bank Umum Swasta Nasional Devisa diterima.

Pengaruh GCG Terhadap Skor Kesehatan

Berdasarkan koefisien regresi, t hitung dan koefisien determinasi $\left(\mathrm{r}^{2}\right)$ pada tabel 2, diketahui bahwa GCG memiliki pengaruh negatif yang tidak signifikan. Dengan demikian, hipotesis yang menyatakan bahwa GCG secara parsial mempunyai pengaruh positif yang signifikan terhadap Skor Kesehatan Bank pada Bank Umum Swasta Nasional Devisa ditolak.

Ketidaksesuaian hasil penelitian dengan teori dikarenakan apabila GCG meningkat, berarti telah terjadi peningkatan jumlah komposisi komisaris independen yang mengakibatkan tata kelola bank menjadi lebih baik. Selama periode penelitian skor kesehatan bank sampel penilitian mengalami penurunan yang dibuktikan dengan tren sebesar -0,05 persen. Hal ini karena kenaiakan skor akibat peningkatan GCG masih lebih kecil daripada turunnya skor akibat faktor yang lain.

Pengaruh ROA Terhadap Skor Kesehatan

Berdasarkan koefisien regresi, t hitung dan koefisien determinasi $\left(\mathrm{r}^{2}\right)$ pada tabel 2, diketahui bahwa ROA memiliki pengaruh positif yang signifikan. ROA memberikan kontribusi sebesar 17,4 persen terhadap skor kesehatan bank. Dengan demikian, hipotesis yang menyatakan bahwa ROA secara parsial mempunyai pengaruh positif yang signifikan terhadap Skor Kesehatan Bank pada Bank Umum Swasta Nasional Devisa diterima.

Kesesuaian hasil penelitian ini apabila ROA menurun, berarti telah terjadi peningkatan laba dengan persentase lebih kecil dibanding persentase peningkatan aset. Selama periode penelitian skor kesehatan bank sampel penilitian mengalami penurunan yang

Pengaruh ETA Terhadap Skor Kesehatan

Berdasarkan koefisien regresi, $\mathrm{t}$ hitung dan koefisien determinasi $\left(\mathrm{r}^{2}\right)$ pada tabel 2, diketahui bahwa ETA memiliki pengaruh positif yang tidak signifikan. ETA memberikan kontribusi sebesar 0,39 persen terhadap skor kesehatan bank. Dengan demikian, hipotesis yang menyatakan bahwa ETA secara parsial mempunyai pengaruh positif yang signifikan terhadap Skor Kesehatan Bank pada Bank Umum Swasta Nasional Devisa Ditolak.

Ketidaksesuaian hasil penelitian dengan teori dikarenakan apabila ETA menurun, berarti telah terjadi peningkatan equity dengan persentase lebih kecil dibanding persentase peningkatan aset. Peningkatan aset lebih banyak menggunakan selain equity, yaitu menggunakan liabilitas sehingga menyebabkan risiko likuiditas meningkat dan skor menurun. Selama periode e-ISSN : 2614-820X 
penelitian skor kesehatan bank sampel penilitian mengalami penurunan yang dibuktikan dengan tren sebesar $-0,05$ persen.

\section{PEMBAHASAN}

Hasil Uji F (Uji Simultan)

Berdasarkan pada hasil Uji $\mathrm{F}$ yang telah dilakukan , maka dapat diperoleh bahwa variabel CKPN, ALR, BOPO, IRR, GCG, ROA dan ETA secara bersama - sama memiliki pengaruh yang signifikan terhadap Skor Kesehatan pada Bank Umum Swasta Nasional Devisa di Indonesia pada periode 2014 sampai dengan 2018. Hal ini menunjukkan bahwa Risiko Usaha, Good Corporate Governance, Proftabilitas dan Capital secara bersama-sama mempunyai pengaruh yang signifikan terhadap Skor Kesehatan pada bank sampel penelitian.

Besarnya pengaruhnya yakni 58,35 persen, yang berarti bahwa perubahan yang terjadi pada Skor Kesehatan pada Bank Umum Swasta Nasional Devisa di Indonesia yang merupakan sampel penelitian dipengaruhi oleh variabel CKPN, ALR, BOPO, IRR, GCG, ROA dan ETA sedangkan sisanya 41,65 persen perubahan pada skor kesehatan bank-bank sampel penelitian dipengaruhi oleh variabel diluar model yang dihasilkan pada penelitian. Hal tersebut diperkirakan karena adanya pengukuran skor menurut InfoBank melibatkan aspek Peringkat Profil Manajemen Risiko, Peringkat Nilai Komposit GCG, Permodalan (CAR), Kualitas Aset (NPL), Rentabilitas (ROA,ROE), Likuiditas (LDR) serta Efisiensi (BOPO dan NIM). Namun pada penelitian ini tidak melibatkan seluruh aspek yang digunakan InfoBank.

Dengan demikian, hipotesis pertama penelitian ini menyatakan bahwa variabel CKPN, ALR, BOPO, IRR, GCG, ROA dan ETA secara bersama-sama memiliki pengaruh yang signifikan terhadap skor kesehatan adalah diterima.
Hasil Uji t (Uji Parsial)

Berdasarkan hasil Uji t diperoleh hasil bahwa dari semua variabel penelitian yaitu CKPN, ALR, BOPO, IRR, GCG, ROA dan ETA yang memiliki pengaruh signifikan terhadap skor kesehatan yakni IRR dan ROA. Penjelasan lebih rincinya yakni sebagai berikut :

1. CKPN

Variabel CKPN secara parsial mempunyai pengaruh negatif tidak signifikan terhadap Skor Kesehatan Bank Umum Swasta Nasional Devisa di Indonesia dengan memberikan pengaruh sebesar 0,59 persen pada periode tahun 2014 sampai dengan 2018.

Berdasarkan hasil analisa yang dilakukan dapat diketahui bahwa risiko kredit yang diukur dengan menggunakan CKPN berpengaruh negatif tidak signifikan terhadap skor kesehatan. Sehingga dapat disimpulkan bahwa hipotesis kedua yang menyatakan bahwa CKPN secara parsial mempunyai pengaruh negatif yang signifikan terhadap Skor Kesehatan Bank Umum Swasta Nasional Devisa di Indonesia adalah ditolak.

Ketidaksignifikan pengaruh CKPN terhadap skor kesehatan bank disebabkan karena selama periode penelitian mulai tahun 2014 sampai dengan 2018 terjadi peningkatan CKPN bank sampel penelitian yang dibuktikan dengan rata-rata tren secara keseluruhan yakni sebesar 0,15 persen. Hal tersebutlah yang menjadikan variabel CKPN menjadi tidak signifikan.

Hasil penelitian ini dibandingkan dengan peneliti sebelumnya yang dilakukan oleh Mi Razul Amrullah, Herizon (2018) dimana hasil penelitian ini tidak mendukung dan tidak sesuai dengan penelitian sebelumnya karena hasil penelitian sebelumnya menemukan bahwa variabel CKPN Atas Kredit memiliki pengaruh positif tidak signifikan terhadap skor kesehatan bank. 

Vol. XVII No. 2 |Bulan Juli Tahun 2020

2. ALR

Variabel ALR secara parsial mempunyai pengaruh negatif tidak signifikan terhadap Skor Kesehatan Bank Umum Swasta Nasional Devisa di Indonesia dengan memberikan pengaruh sebesar 0 persen pada periode tahun 2014 sampai dengan 2018.

Berdasarkan hasil analisa yang dilakukan dapat diketahui bahwa risiko likuiditas yang diukur dengan menggunakan ALR berpengaruh negatif tidak signifikan terhadap skor kesehatan. Sehingga dapat disimpulkan bahwa hipotesis ketiga yang menyatakan bahwa ALR secara parsial mempunyai pengaruh yang signifikan terhadap Skor Kesehatan Bank Umum Swasta Nasional Devisa di Indonesia adalah ditolak.

Ketidaksignifikan pengaruh ALR terhadap skor kesehatan bank disebabkan karena selama periode penelitian mulai tahun 2014 sampai dengan 2018 terjadi peningkatan ALR bank sampel penelitian yang dibuktikan dengan rata-rata tren secara keseluruhan yakni sebesar 3,83 persen. Hal tersebutlah yang menjadikan variabel ALR menjadi tidak signifikan.

\section{BOPO}

Variabel BOPO secara parsial mempunyai pengaruh positif tidak signifikan terhadap Skor Kesehatan Bank Umum Swasta Nasional Devisa di Indonesia dengan memberikan pengaruh sebesar 0,03 persen pada periode tahun 2014 sampai dengan 2018.

Berdasarkan hasil analisa yang dilakukan dapat diketahui bahwa risiko operasional yang diukur dengan menggunakan BOPO berpengaruh positif tidak signifikan terhadap skor kesehatan. Sehingga dapat disimpulkan bahwa hipotesis keempat yang menyatakan bahwa BOPO secara parsial mempunyai pengaruh positif yang signifikan terhadap Skor Kesehatan Bank Umum Swasta Nasional Devisa di Indonesia adalah ditolak.
Ketidaksignifikan pengaruh BOPO terhadap skor kesehatan bank disebabkan karena selama periode penelitian mulai tahun 2014 sampai dengan 2018 terjadi peningkatan BOPO bank sampel penelitian yang dibuktikan dengan rata-rata tren secara keseluruhan yakni sebesar 21,86 persen. Hal tersebutlah yang menjadikan variabel ALR menjadi tidak signifikan.

Hasil penelitian ini dibandingkan dengan peneliti sebelumnya yang dilakukan oleh Mi Razul Amrullah, Herizon (2018) dimana hasil penelitian ini tidak mendukung dan tidak sesuai dengan penelitian sebelumnya karena hasil penelitian sebelumnya menemukan bahwa variabel BOPO memiliki pengaruh negatif signifikan terhadap skor kesehatan bank.

4. IRR

Variabel IRR secara parsial mempunyai pengaruh negatif signifikan terhadap Skor Kesehatan Bank Umum Swasta Nasional Devisa di Indonesia dengan memberikan pengaruh sebesar 1,75 persen pada periode tahun 2014 sampai dengan 2018.

Berdasarkan hasil analisa yang dilakukan dapat diketahui bahwa risiko pasar yang diukur dengan menggunakan IRR berpengaruh negatif signifikan terhadap skor kesehatan. Sehingga dapat disimpulkan bahwa hipotesis kelima yang menyatakan bahwa IRR secara parsial mempunyai pengaruh yang signifikan terhadap Skor Kesehatan Bank Umum Swasta Nasional Devisa di Indonesia adalah diterima.

Signifikan pengaruh IRR terhadap skor kesehatan bank disebabkan karena selama periode penelitian mulai tahun 2014 sampai dengan 2018 terjadi peningkatan IRR bank sampel penelitian yang dibuktikan dengan rata-rata tren secara keseluruhan yakni sebesar 1,03 persen. Hal tersebutlah yang menjadikan variabel IRR menjadi signifikan. 

Vol. XVII No. 2 |Bulan Juli Tahun 2020

\section{GCG}

Variabel GCG secara parsial mempunyai pengaruh negatif tidak signifikan terhadap Skor Kesehatan Bank Umum Swasta Nasional Devisa di Indonesia dengan memberikan pengaruh sebesar 3,68 persen pada periode tahun 2014 sampai dengan 2018.

Berdasarkan hasil analisa yang dilakukan dapat diketahui bahwa Good Corporate Governnace yang diukur dengan menggunakan Komposisi Komisaris Independen berpengaruh negatif tidak signifikan terhadap skor kesehatan. Sehingga dapat disimpulkan bahwa hipotesis keenam yang menyatakan bahwa GCG secara parsial mempunyai pengaruh positif signifikan terhadap Skor Kesehatan Bank Umum Swasta Nasional Devisa di Indonesia adalah ditolak.

Ketidaksignifikan pengaruh GCG terhadap skor kesehatan bank disebabkan karena selama periode penelitian mulai tahun 2014 sampai dengan 2018 terjadi peningkatan GCG bank sampel penelitian yang dibuktikan dengan rata-rata tren secara keseluruhan yakni sebesar 0,76 persen. Hal tersebutlah yang menjadikan variabel GCG menjadi tidak signifikan.

Hasil penelitian ini dibandingkan dengan peneliti sebelumnya yang dilakukan oleh RR. Iramani, Muazaroh Muazaroh, Abdul Mongid (2018) dimana hasil penelitian ini tidak mendukung dan tidak sesuai dengan penelitian sebelumnya karena hasil penelitian sebelumnya menemukan bahwa variabel GCG memiliki pengaruh positif dan secara langsung mempengaruhi kinerja bank.

6. ROA

Variabel ROA secara parsial mempunyai pengaruh positif signifikan terhadap Skor Kesehatan Bank Umum Swasta Nasional Devisa di Indonesia dengan memberikan pengaruh sebesar 17,4 persen pada periode tahun 2014 sampai dengan 2018.
Berdasarkan hasil analisa yang dilakukan dapat diketahui bahwa rentabilitas atau profitabilitas yang diukur dengan menggunakan ROA berpengaruh positif signifikan terhadap skor kesehatan. Sehingga dapat disimpulkan bahwa hipotesis ketujuh yang menyatakan bahwa ROA secara parsial mempunyai pengaruh positif signifikan terhadap Skor Kesehatan Bank Umum Swasta Nasional Devisa di Indonesia adalah diterima.

Signifikan pengaruh ROA terhadap skor kesehatan bank disebabkan karena selama periode penelitian mulai tahun 2014 sampai dengan 2018 terjadi peningkatan ROA bank sampel penelitian yang dibuktikan dengan rata-rata tren secara keseluruhan yakni sebesar 0,04 persen. Hal tersebutlah yang menjadikan variabel ROA menjadi signifikan.

Hasil penelitian ini dibandingkan dengan peneliti sebelumnya yang dilakukan oleh RR. Iramani, Muazaroh Muazaroh, Abdul Mongid (2018) dimana hasil penelitian ini mendukung dan sesuai dengan penelitian sebelumnya karena hasil penelitian sebelumnya menemukan bahwa variabel ROA memiliki pengaruh positif signifikan

\section{ETA}

Variabel ETA secara parsial mempunyai pengaruh positif tidak signifikan terhadap Skor Kesehatan Bank Umum Swasta Nasional Devisa di Indonesia dengan memberikan pengaruh sebesar 0.39 persen pada periode tahun 2014 sampai dengan 2018.

Berdasarkan hasil analisa yang dilakukan dapat diketahui bahwa capital atau permodalan yang diukur dengan menggunakan ETA berpengaruh positif tidak signifikan terhadap skor kesehatan. Sehingga dapat disimpulkan bahwa hipotesis kedelapan yang menyatakan bahwa ETA secara parsial mempunyai pengaruh positif yang signifikan terhadap Skor Kesehatan Bank Umum Swasta Nasional Devisa di Indonesia adalah ditolak. 
Ketidaksignifikan pengaruh ETA terhadap skor kesehatan bank disebabkan karena selama periode penelitian mulai tahun 2014 sampai dengan 2018 terjadi peningkatan ETA bank sampel penelitian yang dibuktikan dengan rata-rata tren secara keseluruhan yakni sebesar 0,44 persen. Hal tersebutlah yang menjadikan variabel ETA menjadi tidak signifikan.

\section{KESIMPULAN}

CKPN, ALR, BOPO, IRR, GCG, ROA

dan ETA secara bersama-sama memiliki pengaruh yang signifikan terhadap Skor Kesehatan Bank Umum Swasta Nasional Devisa di Indonesia pada periode 2014 sampai dengan 2018. CKPN, ALR, GCG secara parsial memiliki pengaruh negatif tidak signifikan terhadap Skor Kesehatan Bank Nasional Devisa Swasta di Indonesia. BOPO dan ETA secara parsial memiliki pengaruh positif tidak signifikan terhadap Skor Kesehatan Bank Nasional Devisa Swasta di Indonesia. IRR secara parsial memiliki pengaruh negatif signifikan terhadap Skor Kesehatan Bank Nasional Devisa Swasta di Indonesia. ROA secara parsial memiliki pengaruh positif signifikan terhadap Skor Kesehatan Bank Nasional Devisa Swasta di Indonesia. Diantara CKPN, ALR, BOPO, IRR, GCG, ROA dan ETA yang memiliki pengaruh paling dominan terhadap skor kesehatan Bank Umum Swasta Nasional Devisa di Indonesia adalah ROA.

Penelitian ini memiliki keterbatasan yakni: Periode penelitian yang digunakan mulai tahun 2014 sampai dengan tahun 2018. Jumlah variabel yang diteliti terbatas, yakni CKPN, ALR, BOPO, IRR, GCG, ROA dan ETA serta tidak menggunakan variabelvariabel lain yang ada pada biro riset InfoBank yang meliputi CAR, NPL, ROE, LDR dan NIM. Subyek penelitian terbatas pada Bank Umum Swasta Nasional Devisa di Indonesia yaitu semua Bank Umum Swasta Nasional Devisa periode 2014 sampai dengan
2018 bukan termasuk bank syariah. Adanya keterbatasan atau kurangnya kelengkapan data mengenai laporan publikasi dari keseluruhan opulasi penelitian, sehingga menyebabkan sampel penelitian hanya ada tiga puluh satu bank. Berdasarkan kesimpulan dan keterbatasan penelitian, maka saran yang dapat diberikan dari penelitian ini adalah sebagai berikut:

Bagi industri perbankan, pada bank sampel penelitian terutama PT. Bank JTrust Indonesia,Tbk yang memiliki rata-rata skor kesehatan terendah dari variabel penelitian yang digunakan yakni sebesar 57,41 persen serta memiliki rata-rata tren positif yang cenderung sedikit meningkat yakni sebesar 2,14 persen. Untuk ditahun selanjutnya diharapkan PT. Bank JTrust Indonesia,Tbk mampu meningkatkan skor kesehatan bank dengan cara menekan profil risiko serta mampu meningkatkan kinerja penerapan Good Corporate Governance, permodalan, kualitas aset, rentabilitas, likuiditas dan mengefisiensikan pengeluaran pada aspek biaya operasional bank. Dan juga memberikan informasi yang lengkap setiap tahunnya pada Biro Riset Infobank.

Bagi peneliti selanjutnya, apabila akan mengambil tema yang serupa, sebaiknya menambah periode penelitian yang lebih panjang dari lima tahun serta periode tahun pelaporan yang terbaru agar nantinya dapat menghasilkan penelitian yang lebih baik. Menambah jumlah sampel penelitian lebih banyak agar mendapatkan hasil yang lebih baik. Menambah variabel bebas penelitian yakni variabel - variabel yang digunakan oleh Biro Riset Infobank yang sebelumnya belum digunakan dalam penelitian ini seperti CAR, NPL, ROE, LDR dan NIM. Serta mengacu pada kriteria skor penilaian tingkat kesehatan bank yang dipublikasikan oleh Biro Riset Infobank. 

Vol. XVII No. 2 |Bulan Juli Tahun 2020

\section{DAFTAR PUSTAKA}

Abdul Razak Abdul Hadi, Tulus Suryanto, \& Eddy Yap Tat Hiung (2018), Bank Soundness and Sustainability-Evidence From Middle Easr, Indian Sub-Continent and African Banks, Journal of Islamic Economics and Business Volume 3, No I 2018, Pages 97-106.

Azeharie, Willis Marcellina $\mathrm{P}$, Wahjono, \& Sentot Imam P (2017), Analysis Of Bank Health At Indonesia State-owned Bank Using Rgec Method At Bri,Bni And Bank Mandiri For Periods 2011-2015, 3 rd International Conferences on Information Technology and Business (ICITB), 7th Dec 2017, pages

Biro Riset Infobank, 2015. Rating 120 Bank Versi Infobank Edisi Juni No 437, Majalah Infobank, Jakarta, Biro Riset Infobank.

Biro Riset Infobank, 2016. Rating 118 Bank Versi Infobank Edisi Juli No 451, Majalah Infobank, Jakarta, Biro Riset Infobank.

Biro Riset Infobank, 2017. Rating 118 Bank Versi Infobank Edisi Juli No 446 , Majalah Infobank, Jakarta, Biro Riset Infobank.

Biro Riset Infobank, 2018. Rating 115 Bank Versi Infobank Edisi Juli No 480 , Majalah Infobank, Jakarta, Biro Riset Infobank.

Biro Riset Infobank, 2019. Rating 114 Bank Versi Infobank Edisi Juli No 494 , Majalah Infobank, Jakarta, Biro Riset Infobank.

Md. Zahidur Rahman , Md. Shohidul Islam (2018), Use of CAMEL Rating Framework: A Comparative Performance Evaluation of Selected Bangladeshi Private Comercial Banks, International Journal
Economics and Finance: Vol.10, No. I 2018, Pages 120-128.

Mi Razul Amrullah, Herizon (2018), The Influence of Business Risk and Good Corporate Governance to Soundness Score on Foreign Exchange National Private Banks in Indonesia, Journal of Business and Banking, Vol 8 Number I Mei-Oktober 2018, pages 1-24.

Otoritas Jasa Keuangan. 2016. Jakarta. Peraturan Otoritas Jasa Keuangan Nomor 4/POJK.03/2016. Penilaian Tingkat Kesehatan Bank Umum.

Otoritas Jasa Keuangan. 2016. Jakarta. Peraturan Otoritas Jasa Keuangan Nomor 18/POJK/.03/2016. Penerapan Manajemen Risiko Bagi Bank Umum.

Otoritas Jasa Keuangan. 2016. Jakarta. Peraturan Otoritas Jasa Keuangan Nomor 55 /POJK.03/2016. Penerapan Tata Kelola Bagi Bank Umum

Otoritas Jasa Keuangan. 2017. Jakarta. Surat Edaran Otoritas Jasa Keuangan Nomor 14/SEOJK.03/2017. Penilaian Tingkat Kesehatan Bank.

Otoritas Jasa Keuangan,(www.ojk.go.id). Laporan Keuangan Publikasi Bank. Diakses Pada Tanggal 06 April 2020.

RR. Iramani, Muazaroh Muazaroh, \& Abdul Mongid (2018), Positive Contribution Of The Good Corporate Governance Rating To Stability And Performance : Evidence From Indonesia, Problems and Perspectives in Management, Volume 16, Issue 2, pages 1-1.

Undang-Undang Republik Indonesia.1998. Jakarta. Nomor 10 Tahun 1998. Tentang Perbankan. 